\title{
JAKOŚCIOWE SZACOWANIE PEWNYCH ZAGROŻEŃ GENERUJACYCH RYZYKO UBEZPIECZENIOWE
}

Włodzimierz Szkutnik

prof. dr hab., Uniwersytet Ekonomiczny w Katowicach

Alicja Wolny

dr, Uniwersytet Ekonomiczny w Katowicach

\section{Wprowadzenie}

W wielu przypadkach szacowania ryzyka pojawia się fundamentalna trudność wynikająca $z$ braku historii zdarzeń wpływających na jego ekspozycję na ryzyko i często nie można $\mathrm{z}$ tego powodu korzystać $\mathrm{z}$ opinii ekspertów, gdyż takowych nie ma lub ich sugestie nie są wtedy wartościowe (wiarygodne). Nawet, jeśli możliwe jest ilościowe ujęcie oceny ryzyka to względem stosowanej w takich przypadkach metodyki oceny takie nie są rzetelne lub oceny rzetelne występują bardzo rzadko. Ponadto zdarza się często, że stosowana w podejściu ilościowym metodyka może nie być adekwatna względem badania skutków zdarzeń mających wpływ na realizacje ryzyka. Innym aspektem jest $\mathrm{w}$ takim przypadku brak możliwości uwzględnienia w stosowanej metodyce ryzyka wywołanego zagrożeniem spowodowanym rozmyślnie.

Generalnie ryzyko, jako sformalizowana niepewność, powinno być szacowane metodami dającymi możliwość jego oceny metodami wiarygodnymi wynikającymi z obiektywnie uzasadnionych przesłanek metodami sformalizowanymi w modelu statystycznym lub ekonometrycznym. Ograniczenia obiektywne często jednak uniemożliwiają takie szacowanie ryzyka i mamy wtedy jego „substytut”, jakim jest niepewność. Wynika stąd tylko jeden sposób oszacowania takiego „ryzyka” w postaci jakościowej oceny: opisu słownego, punktowego opartego na przypuszczeniach uwiarygodnionych wiedzą nabytą lub wynikająca z przekonania. Zwrócić należy tu uwagę, że ryzyko i niepewność są w istocie $\mathrm{z}$ tej samej kategorii semantycznej. 
W realnych warunkach, w jakich występuje zagrożenie powodujące szkody ryzyko nim wywołane szacowane jest metodą formalnie opartą na teorii prawdopodobieństwa, właściwą dla tego ryzyka, a semantyczny zamiennik ryzyka, jakim jest niepewność wynikająca z istnienia zagrożeń trudno wycenianych może być szacowana metodami jakościowymi.

Innym zagadnieniem są obiektywne przeszkody pojawiające się przy szacowaniu wartości szkód wywołanych określonym zagrożeniem. Skłaniają one do ujęcia szacowanego ryzyka w ramy jakościowej oceny. Ocena taka jest ekwiwalentem skorelowanym z zarządzaniem ryzykiem $i$ jest procesem mającym na celu ograniczenie go do akceptowalnego poziomu. Poziom ten jest elementem subiektywnego procesu decyzyjnego i sam w sobie jest składnikiem jakościowej oceny. $Z$ reguły składa się na jego ocenę kilka etapów, z których najbardziej rozpoznawalnym jest etap planowania, rozwoju i testowania. Natomiast w samym procesie zarządzania ryzykiem wyróżniane są procesy identyfikacji, kontroli i zmniejszania prawdopodobieństwa zaistnienia niepewnych zdarzeń mających wpływ na zrealizowanie się określonego ryzyka ubezpieczeniowego. Są to ogólnie znane w literaturze sekwencje pewnych stałych czynności zalecanych do wykonania przy prowadzeniu większości działalności biznesowych. Identyfikacja ryzyka obejmuje natomiast samą analizę ryzyka, w której kluczowym zadaniem jest ujawnienie obszarów, na które należy zwrócić szczególna uwagę. Istnieje ścisły związek między obszarem szacowania ryzyka a jego minimalizowaniem. Jest to istota zarządzania ryzykiem. Informacje te podaje m.in. Whitman w pracy [Whitman i Mattorda 2006] w kontekście bezpieczeństwa informacji. Wymienione są tam następujące etapy zarządzania ryzykiem: identyfikacja, oszacowanie wpływu ryzyka na działalność, oszacowanie słabych punktów i zagrożeń, oszacowanie bieżących środków osłabienia ryzyka.

W systemowym spojrzeniu na zarządzanie ryzykiem bezpieczeństwo ubezpieczanych obiektów ma bezpośredni wpływ na szacowane ryzyko, co najprościej ujmując przekłada się na przyjmowaną przez ubezpieczyciela składkę. Dlatego też zarządzanie takim ryzykiem jest regulowane wieloma uregulowaniami prawnym, m.in. takimi jak Solvency II czy w pośredni sposób zgodny z ISO/IEC 27001:2005 i dalszymi modyfikacjami tych uregulowań.

Niedokładna identyfikacja potrzeb stawianych wobec ubezpieczanych ryzyk szacowanych zarówno metodami ilościowymi jak i stricte jakościowymi w zakresie wypełniania reguł bezpiecznego ich funkcjonowania zgodnego z tymi, które były zakładane przy szacowaniu ryzyka wpływa oczywiście na niedokładność wyznaczanej składki. Nie umożliwia to możliwości uzyskania informacji o kosztach $\mathrm{w}$ analizie uwzględniającej wprowadzanie nowych zabezpieczeń. 
Z tego względu w praktyce przy szacowaniu ryzyka stosowane są metody wnoszące wiele elementów niwelujących wady obu tych metod. Przegląd tych metod, chociaż w nieco innych kontekście, był już w literaturze przedmiotem kilku artykułów. Zatem w zależności od kontekstu dokonamy tu tylko krótkiego ich scharakteryzowania skupiając uwagę na szacowaniu ryzyka ubezpieczeniowego mogącego mieć zastosowanie przy ubezpieczaniu ryzyk nietypowych, raczej rzadko ubezpieczanych lub wtedy, gdy przy szacowaniu szkód stosowane są nietypowe metody dla danej grupy ryzyk oparte na unikalnych metodach kontroli historii zdarzenia wywołującego ryzyko, tak jak może być w przypadku ubezpieczeń komunikacyjnych. Nie będziemy im jednak nadawać szerszej formy egzemplifikacji.

\section{Ryzyko zawodowe - sposoby oceny i identyfikacji}

W tym aspekcie zwraca uwagę ocena ryzyka zawodowego, względem którego istnieją ogólne wymagania prawne wynikające z kodeksu pracy i rozporządzeń odnoszących się do ogólnych przepisów bezpieczeństwa i higieny pracy. Wynika $z$ nich, że pracodawca jest zobowiązany szacować ryzyko związane z pracą i dokumentować wyniki takiej oceny. Nie ma natomiast określonych wymogów odnoszących się do metod oceny ryzyka zawodowego. Dotyczy to zarówno prawa ogólnego jak i szczegółowego dla działów gospodarki narodowej, sekcji i podsekcji działalności oraz rodzajów zagrożeń w przekroju wykonywanych prac. Jedynie ogólne zasady i kryteria oceny ryzyka zawarte są w polskiej normie PN-N-18002:2000. Mają one charakter ogólnych wytycznych (zasady i kryteria) odnośnie ilościowej i jakościowej oceny ryzyka. W tym kontekście oceny ryzyk rzadko szacowanych dla potrzeb ubezpieczeń norma PN-EN 1050:1999 skierowana jest do zasad oceny ryzyka w bezpieczeństwie odnoszącym się do eksploatacji maszyn. Są nimi metody możliwe do zastosowania w ocenie analizy ryzyka poprzez identyfikację zagrożeń. Wśród nich wyróżnić można takie jak, wstępna analiza zagrożeń PHA (Preliminary Hazard Analysis) i stricte metody prognostyczne (analiza wywodząca się od kwestii, które można rozważyć: „co jeśli” albo „co gdy”) WI (Whatif- Analysis), analiza rodzaju błędów i skutków FMEA (Failure Modes and Effects Analysis). Nie są to metody bardzo zaawansowane. Takimi są $\mathrm{w}$ identyfikacji zagrożeń metody należące do metod dedukcyjnych i indukcyjnych, które omówione będą w dalszej części artykułu. Natomiast 
$\mathrm{w}$ innych normach zawarto zasady i metody analizy ryzyka w systemach technicznych odwołujące się zagrożeń i możliwości operacyjnych HAZOP (Hazard and Effects Analysis) i analizę rodzaju błędu i krytyczności skutków (Failure Modes).

Wśród metod specjalnych w identyfikacji zagrożeń są metody analizy drzew logicznych ETA (Event Tree Analysis) i analiza drzewa błędów i uszkodzeń i niezdatności FTA ( Fault Tree Analysis). Obie zostaną wspomniane jeszcze także w innym kontekście. Dodatkowo można wyróżnić także metodę analizy przyczyn i wyników CCA (Cause and Consequence Analysis) oraz metodę analizy czynnika ludzkiego (jego sprawności w skrajnych momentach działania) HRA (Human Reliability Analysis). Natomiast szczegółowe wytyczne odnośnie zasad i metod oceny ryzyka zawodowego można znaleźć w dostępnej literaturze specjalistycznej np. Romanowska-Słomka [2008]. Omówione są w niej dokumentacje oceny ryzyka, a także czynniki szkodliwe dla zdrowia, które mają określony wpływ na ryzyko rozumiane szerzej, nie tylko jako zawodowe. Podawane są w niej także analizy zagrożeń i zasady oceny ryzyka oraz metody i kryteria oceny ryzyka, które charakteryzowane są w kolejnym podrozdziale.

Zaakcentować należy, że w procesie oceny ryzyka, szczególnie zawodowego, zastosowanie znajduje analiza mająca określić poziom akceptowalności ryzyka, o czym nieco szerzej wspomnimy w dalszej części. Przy ocenie ryzyka specyficznego dla danej grupy zagrożonych obiektów należy zwrócić uwagę, aby otrzymane wyniki oceny ryzyka zawodowego były w pełni wystarczające do wyznaczenia jego dopuszczalności oraz właściwego planowania działań korygujących i zapobiegawczych. Ma to związek z nieakcentowaną silnie w obecnie publikowanej literaturze zasadą prewencji. Każda ocena powinna być w pełni zgodna i wystarczająca do wyznaczenia jej dopuszczalności oraz właściwego planowania działań korygujących i profilaktycznych. Zastosowanie znajduje tu zasada "tak niskie, jak jest to możliwe" ALARP (As Low As Reasonable Practicable). Zgodnie z nią można wyróżnić obszary o wysokim poziomie ryzyka, który nie jest możliwy do obniżenia i wtedy ryzyko nie ma z pewnością charakteru ubezpieczanego, obszary z ryzykiem możliwym do zaakceptowania, jeśli będzie monitorowane i w tych warunkach jest możliwość jego ubezpieczenia oraz występują warunki ekonomiczne dla jego redukcji oraz trzeci rodzaj obszarów, w którym ryzyko może nie być brane pod uwagę ze względy na niskie koszty spowodowane jego realizacją i nie występowaniem konieczności jego kontroli ze względu na nieprzewidywanie jego zwiększenia.

W dalszej części artykułu uwaga skupiona zostanie na szacowaniu ryzyka sposobami mieszanymi. Nie będziemy indywidualizować rodzaju oceny, lecz wprowadzimy to zagadnienie w aspekcie metodycznym 
i skierowanym do problemów paraubezpieczeniowych, przez co rozumieć będziemy ryzyko potencjalnie możliwe do ubezpieczenia w ZU, lecz nie mające takich cech, by występowała skłonność zakładów ubezpieczeniowych do ich ochrony zawartej w polisie ubezpieczeniowej. Dotyczy to scharakteryzowanych wyżej ryzyk zawodowych, wspomnianych ryzyk nietypowych, jak ochrona zasiewów przed zwierzyną, obszarów leśnych przed rozmaitymi zagrożeniami, niepewności pojawiającej się na polu bitwy, manewrach wojskowych, treningach mających różną genezę itp.

\section{Pewne szczególne kryteria w metodach oceny ryzyka}

Ocena ryzyka mającego charakter nietypowy, ale nie tylko, polega na określeniu wielkości (poziomu) ryzyka dla poszczególnych zdarzeń związanych $\mathrm{z}$ zagrożeniami powodującymi straty na określonych stanowiskach (rolnych, leśnych, budów, produkcyjnych). W takich przypadkach identyfikacja zagrożeń jest nieodzownym działaniem mającym w ocenie ryzyka priorytetowe znaczenie. Zgodnie z pojmowaną w różny sposób, ale dla danego przypadku jednoznacznie, na stanowiskach podlegających potencjalnemu zagrożeniu mogą mieć zastosowanie miary ryzyka zarówno bardzo prozaiczne (opis słowny) jak i liczbowe (wskaźniki). Wynikają one z przyjętych kryteriów przy ocenie ryzyka.

Wtedy ocena wielkości ryzyka wywoływanego określonymi zagrożeniami identyfikowanymi na stanowiskach podlegających potencjalnemu zagrożeniu polega na ustaleniu: możliwości (prawdopodobieństwa, częstości) wystąpienia zagrożeń, potencjalnych skutków (następstw, konsekwencji, szkód, strat) wystąpienia zagrożeń.

Odnosi się to do takich czynników generujących ryzyko, dla których wyznaczone zostały, określone przez rodzaj zagrożenia normy umożliwiające ocenić wielkość ryzyka metodami statystycznymi, jak np. przez porównanie średnich wartości tych czynników (mogą to być np. stężenia lub natężenia szkodliwych substancji) z tymi normami.

W odniesieniu do czynników niemierzalnych (obejmujących czynniki szkodliwe dla zdrowia, dla których nie określono wartości dopuszczalnych i pozostałe czynniki występujące w środowisku pracy, np. mechaniczne) wielkość ryzyka można wyznaczyć za pomocą indywidualnie określonej przez specjalistów określonej metody oceny ryzyka.

Jeśli proste metody oceny ryzyka są niewystarczające, wtedy decyzja o jego wycenie powinna być zwrócona ku metodom zaawansowanym, 
jeśli możliwe jest ich zastosowanie, tzn. istnieją ku temu wystarczające przesłanki (dostępne dane, istnienie możliwości zaimplementowania znanych metod, zapewnienie udziału specjalistów, grupowe podejmowanie decyzji).

W praktyce taka forma wyboru sposobu oceny ryzyka wynika $z$ istnienia możliwości zastosowania jednej z możliwych strategii podejmowania decyzji wynikającej z zastosowanej zaawansowanej metody jakościowej oceny ryzyka. Sprowadza się to w realnych warunkach do strategii indywidualnej decyzji wynikającej z operacyjnej wiedzy decydenta, strategii grupowej sprowadzającej się $\mathrm{w}$ formalnym przekazie do wypełnienia formularza z kolektywnej decyzji członków zespołu lub strategii wynikającej z sondażowej opinii ekspertów. W strategii sondażowej uśrednia się wyniki ocen zawartych w indywidualnych kartach.

Wynik strategii indywidualnej stosowany może być dla marginalnej linii biznesowej prowadzonej w ZU i nie może być stosowany dla modułów zagregowanych, jak np. ryzyka ubezpieczeń majątkowych, ryzyka ubezpieczeń na życie, w module zdrowotnym, w dostosowaniu ryzyka $\mathrm{z}$ tytułu zdolności rezerw techniczno-ubezpieczeniowych i podatków odroczonych do pokrywania strat. Nie może być też stosowany $\mathrm{w}$ module ryzyka operacyjnego, rynkowego czy ryzyka niewykonania zobowiązań przez kontrahenta. Dla wymienionych strategii zastosowane muszą być zaawansowane metody lub specyficzne formuły nie zawsze oparte na szczególnie zaawansowanych metodach statystycznych. Zatem decyzje indywidualne są charakterystyczne dla mniejszej rangi linii biznesowych oraz dotyczyć powinny decyzji o mniejszej randze. W liniach biznesowych o dużych zasobach kapitałowych lub modułach, jak wyżej wymienione, a generalnie dla istotnych problemów decyzyjnych np. odnoszących się do zagrożenia życia czy zdrowia grup ludzi, decyzje indywidualne mogą być obarczone dużym błędem. Wynika to $z$ reguły z subiektywnego postrzegania problemu przez decydenta, niedokładnych i niepełnych danych i indywidualnie występującego ryzyka operacyjnego. Można tu przytoczyć przykład generowania ryzyka przy tzw. insider tradingu (ang.), który występuje w spółkach giełdowych, przy możliwości wykorzystania informacji niejawnych dotyczących możliwości inwestowania na giełdzie przez osoby mające dostęp do takich informacji.

Decyzje grupowe eliminują większość niedoskonałości decyzji indywidualnych, ale $\mathrm{z}$ ich zastosowaniem mogą być związane duże koszty wypracowania decyzji, wydłużenie czasu na podjęcie decyzji, konieczność pogodzenia sprzecznych decyzji, możliwość zdominowania grupy przez jedną osobę, zależności służbowe i czynniki stricte polityczne związane z podległością jednostek nadzorujących zarządy ZU, jak np. KNF czy instytucje celne bezpośrednio podlegające rządowym decydentom z MF. 
Cały ten kompleks uwarunkowań wpływa na wydłużenie decyzji i może ją znacząco zniekształcać w kierunku negatywnym.

Trzeci rodzaj strategii jest najbardziej zobiektywizowana formę procesu decyzyjnego. W szeregu licznych przypadkach wyceny ryzyka sondaż opinii ekspertów daje podstawy do wyeliminowania dwóch podstawowych ograniczeń drugiej strategii, jakimi są wyeliminowanie skrajnych opinii ekspertów oraz zespół, zwykle negatywnych cech charakterystycznych dla wypracowania obiektywnej oceny. Ten swoisty syndrom grupowego myślenia jest charakterystyczny dla zespołów zdominowanych przez autokratycznych decydentów. Narzucają oni swój, z reguły błędny punkt widzenia na dany problem.

\section{Zależność sposobu oceny ryzyka od celu - dobór metod}

Oczywista zależność doboru sposobu oceny ryzyka zależy m.in. od celu badań i ze względu na wielość metod takiej oceny należy uwzględniać także zależność stopnia dokładności i zasadności przyjęcia danej metody oraz tego, w jakiej postaci powinny być wyrażone wyniki. $Z$ tego względu, szczególnie dla nietypowych ryzyk, które powinny być poddane ochronie, także ubezpieczeniowej, nie istnieją jednoznaczne sposoby oceny takiego ryzyka. Wynika to zarówno ze specyfiki otoczenia, w jakich może być zrealizowane dane ryzyko, rożnych form zagrożeń a także m.in. $\mathrm{z}$ istnienia systemowej rozmaitości i różnorodności obiektów otaczających takie ryzyko, ich form organizacji a także czysto subiektywnych czynników i nawet behawioralnych, generowanych przez czynnik ludzki, wpływający na reakcje aktywujące zrealizowanie się ryzyka.

Metody oceny ryzyka różnią się między sobą wieloma cechami. Wynikają one m.in. $\mathrm{z}$ sposobu postępowania podczas zbierania informacji o ryzyku, posiadanego zasobu informacji przydatnych w ocenie ryzyka, rodzajem stosowanych kryteriów i zakresem ich zastosowań.

Wymogi stawiane przy wyborze określonej metody oceny ryzyka są zależne od splotu wielu okoliczności, których spełnienie jest niezbędne. Dotyczy to takich kwestii jak: adekwatność stosowanej metody w danej linii biznesowej ZU, kwalifikacji ekspertów oceniających ryzyko itp.

Aby dobór metod, od których spełnienia zależy właściwa wycena ryzyka w ZU był odpowiedni, powinny być spełnione obiektywne warunki wyceny tego ryzyka i uregulowania prawne. Także zależy on od wspomnianych już linii biznesowych lub modułów ubezpieczanych ry- 
zyk. Z reguły jest on związany z wieloma zespołami warunków i często ma charakter nie do końca formalnie domknięty. Dlatego należy także uwzględnić rodzaj i zakres czynności prowadzonych w linii biznesowej, specyfikę danej linii biznesowej oraz charakterystyczne ujęcie wyceny ryzyka, jak złożony jest proces samej wyceny i liczebość ubezpieczanych ryzyk.

W kontekście klasyfikacji metod oceny ryzyka można wyróżnić wiele różnych metod. W ogólnej systematyce są nimi metody indukcyjne i dedukcyjne. $\mathrm{W}$ ich ramach zawarte są oczywiście metody będące obiektem prowadzonych tu rozważań, a więc ilościowe i jakościowe. Do metod, które je charakteryzują zaliczyć można:

- tablicowe, wskaźnikowe, graficzne,

- oceny prawdopodobieństwa/częstości i skutków/konsekwencji,

- oceny obszarów ekspozycji na ryzyko obiektów objętych ochroną ubezpieczeniową, zagrożeń dla zdrowia i środowiska,

- oceny systemów otaczających działalność człowieka, techniki, infrastruktury i środowiska.

Podział metod oceny ryzyka zależy głównie od sposobu opisu dostępnych danych i informacji oraz od rodzaju metod oceny. Wpływa do wyraźnie na rodzaj sposobu oceny.

Dla metod ilościowych kryterium szczegółowym jest wspomniany już zasób dostępnych danych statystycznych, a podział na metody dedukcyjne i indukcyjne wynika $\mathrm{z}$ istoty analitycznego, opartego na prawach logiki, sposobu wnioskowania.

W ujęciu dedukcyjnym wykorzystuje się tzw. zasadę „od ogółu do szczegółu" znaną i stosowaną m.in. w modelowaniu zjawisk, gdzie wnioski szczegółowe wynikają z logicznego następstwa zdarzeń (efekt domina). W dedukcyjnym badaniu stosowane jest podejście retrospektywne. W takich uwarunkowaniach możliwe zidentyfikowanie przyczyn dla zdarzeń, które zaistniały. Przykładem zastosowania dedukcji jest m.in. analiza roszczeń z tytułu realizacji określonych okoliczności warunkujących ryzyko. Natomiast przykładową metodę dedukcyjną można zaprezentować w analizie drzewa błędów FTA (Fault Tree Analysis). Jest to metoda używana do analizy przyczyn inicjujących zrealizowanie się ryzyka. Modelowana jest tu wizualizacja logicznych związków pomiędzy rożnymi czynnikami wpływającymi na ekspozycję ubezpieczanego obiektu na ryzyko. Zatem metoda FTA jest zaawansowaną, dedukcyjną techniką. W identyfikacji i analizie czynników, które bezpośrednio eksponują ryzyko ubezpieczeniowe rozważane są ewentualne przyczyny niepożądanych zdarzeń wpływających na realizację takiego ryzyka. Analiza drzewa błędów (FTA) jest graficznym modelem zależności przyczynowoskutkowych. Różni się ona od swego analogu drzewa zdarzeń ETA (Event 
Tree Analysis) kierunkiem budowy i jest budowana w przeciwnym kierunku niż drzewo zdarzeń ETA. Dzięki schematowi FTA zostają zilustrowane przyczyny, których skutek określany jest, jako niepewne zdarzenie bądź ryzyko.

W metodzie drzewa błędów FTA identyfikuje się najpierw zdarzenia końcowe (szczytowe). W dalszej kolejności postępowanie w tej metodzie prowadzi do wyznaczenia ścieżek krytycznych prowadzących do zdarzenia wywołującego zdarzenie związane $\mathrm{z}$ realizacją ubezpieczonego ryzyka.

W analizie drzewa zdarzeń (ETA) postępuje się odwrotnie i podąża się od przyczyn do skutków. Zatem drzewo takie jest obrazem wyniku realizacji ryzyka, i opisuje progresję zdarzeń od początkowego do końcowego wywołującego ubezpieczeniowe ryzyko.

Metody indukcyjne wykorzystują tzw. zasadę „od szczegółu do ogółu”, gdzie wnioski ogólne wynikają z obserwacji zdarzeń szczegółowych i weryfikacji hipotez. Badania oparte są na podejściu prospektywnym, które pozwala na wykrycie uwarunkowań i przyczyn, które mogą doprowadzić do określonych zdarzeń. Przykładem zastosowania indukcji jest m.in. ocena ryzyka zawodowego, a przykładem metody indukcyjnej - analiza drzewa zdarzeń ETA.

Metody jakościowe służą do jakościowej analizy faktów, zjawisk i procesów, w której cele są wyrażane opisowo za pomocą określeń słownych. Badania koncentrują uwagę na podejściu systemowym, które pozwala na całościową charakterystykę badanych zjawisk, określenie granic systemu, struktury systemu, zbioru elementów i relacji zachodzących między nimi. Przykładowe metody jakościowe to listy kontrolne i analiza „co jeśli”. Metody ilościowe służą do ilościowej analizy faktów, zjawisk i procesów, w której cele są wyrażane w odpowiednich jednostkach miary za pomocą wartości liczbowych. Badania koncentrują uwagę na podejściu statystycznym, które pozwala na liczbową charakterystykę badanych zjawisk, weryfikację wiarygodności wyników, dobór odpowiednich miar i wskaźników.

Niektóre metody występują w literaturze pod tą samą nazwą w dwóch wersjach, jedna służy do identyfikacji zagrożeń, druga do oszacowania ryzyka, np. metoda wstępnej analizy zagrożeń PHA, analizy bezpieczeństwa pracy JSA.

Wśród metod oceny ryzyka można wyróżnić m.in. podział na metody służące wyłącznie do oszacowania ryzyka (metoda Score Risk) lub metody łączące identyfikację zagrożeń i oszacowanie ryzyka (np. analiza drzewa zdarzeń ETA, analiza drzewa błędów FTA), zwane także metodami analizy ryzyka. 


\section{Metody jakościowe szacowania ryzyka}

Przy wycenie ryzyka uwzględnić potrzeba możliwe do zebrania dane i informacje o zagrożeniach i rodzaju ryzyka. W prezentowanych niżej przykładach wyceny ryzyka przyjmiemy, że dane i informacje o zagrożeniach i samym ryzyku są zgromadzone metodami ogólnie dostępnymi. Na przykład dla ryzyka zawodowego mogą być stosowane:

- metoda analizy dokumentów i metoda list kontrolnych, które powinny być adekwatne do rodzaju i sposobu wykonywania prostej pracy na stanowisku,

- powyższe metody stosowane dla prostego stanowiska powinny być uzupełnione metodą obserwacji i metoda sondażu, czyli technika wywiadu, jako metody analizy na stanowisku złożonym.

W zakresie obejmującym stanowiska złożone, metody powyższe powinny być zastąpione bardziej zaawansowanymi metodami, takimi jak omówione wyżej metody dedukcyjne i indukcyjne, które mogą mieć charakter zarówno metod ilościowych jak i jakościowych.

W drugim etapie zastosowane powinny być metody identyfikacji zagrożeń - kilka $z$ nich było scharakteryzowanych już we wcześniejszym podrozdziale.

Jako metodę o charakterze indukcyjnym i jakościowym można zastosować metodę WI (co jeśli, jeśli, co się zdarzy). Przy jej zastosowaniu ustalane są przyczyny i warunki, w jakich występują zagrożenia. W procedurze wywiadu lub „burzy mózgów” można antycypować różne możliwe zaburzenia procesu pracy lub nawet ubezpieczanego mienia materialnego i niematerialnego i oceniać straty powstałe $\mathrm{w}$ efekcie ich zaistnienia. Zatem zakres analizy identyfikacji zagrożeń obejmuje tu zarówno poddany ocenie obiekt - stanowisko pracy, jak i czynnik ludzki. W tym przypadku pojawia się w analizie konieczność zrealizowania takich etapów jak: rozpoznanie obiektu, identyfikacja zagrożeń będących podstawą ekspozycji obiektu na ryzyko oraz zlokalizowanie odpowiedzi obiektu na zagrożenia będące przyczyną jego ekspozycji na ryzyko.

Inną możliwą do zastosowania metodą identyfikacji ryzyka może być metoda JSA (Job Safety Analysis), w której analizowane jest bezpieczeństwo pracy. Jest to metoda indukcyjna i może być albo jakościowa albo ilościowa. W tym przypadku identyfikacja zdarzeń wpływających na ekspozycję obiektu na ryzyko łączona jest $\mathrm{z}$ realizowanymi zadaniami, których cele powinny być określone i które powinny być skojarzone z czynnościami wykonywanymi przy ich realizacji. Należy ustalić, poprzez odpowiednie rozpoznanie, zagrożenia mogące się pojawiać przy wykonywaniu tych czynności a potem powinno nastąpić określenie wielkości ryzyka wyni- 
kającego $\mathrm{z}$ ich wykonywania. Zatem jest to typowa metoda indukcyjna. Po zidentyfikowaniu ryzyka można przystąpić do jego analizy i wyceny.

W ostatnich dwóch rozdziałach odniesiemy się do specyficznej metody gromadzenia danych przy zastosowaniu technik telemetrycznych w ubezpieczeniach komunikacyjnych oraz określenie potencjalnego ryzyka na podstawie oszacowanych poziomów zagrożenia.

\section{Sposób zbierania danych oparty na technikach telemetrycznych wpływający na ocenę ryzyka komunikacyjnego}

Innym podejściem do zagadnieniem oceny ryzyka a jednocześnie umożliwiającym wyznaczanie składki ubezpieczeniowej jest stosunkowo wysoko zmotywowany potrzebami praktyki ubezpieczeniowej zmodyfikowany sposób zbierania danych o zdarzeniach komunikacyjnych. Przykładowo w ubezpieczeniach komunikacyjnych dane reprezentujące portfel polis, są wielowymiarowym konglomeratem, w którym każda polisa opisywana jest przez różnego rodzaju czynniki wpływające na szkodowość. W najprostszym przypadku, gdy portfel wszystkich polis można potraktować jako portfel jednorodny każdej polisie można przypisać jednakową składkę. Powstaje tu konieczność podjęcia jakościowego charakteru decyzji związanej $\mathrm{z}$ kwestią rozwiniętą $\mathrm{w}$ pytaniach: czy kierowca pojazdu klasy ekonomicznej jest skłonny w ubezpieczeniu AC zapłacić taką wartość składki, która pokryje także wartość wypadku samochodu luksusowego?, czy kierowca jeżdżący ostrożnie jest skłonny w ubezpieczeniu OC zapłacić taką samą składkę jak kierowca brawurowy? Rozstrzygniecie tej kwestii wiążąca się z odpowiedzią na te pytania jest raczej zdecydowanie negatywna. Stąd zakłady ubezpieczeniowe skłaniają się w coraz większym stopniu do takiej wyceny ryzyka a zatem do takiego ustania składki, głownie OC, by proces wyceny był jak najbardziej spersonalizowany. Oczywiście przy takim stanowisku ZU, w wycenie ryzyka dominować muszą metody jakościowej wyceny. Związany z tym efekt polega na sklasyfikowaniu portfela indywidualnie do potrzeb i kondycji finansowej ZU i w konsekwencji prowadzi do powstania subiektywnie wyznaczonych bardzo licznych podgrup portfeli o tej samej składce. W skrajnym przypadku liczba tych podgrup może być równa liczbie polis, gdy każde ryzyko będzie wyceniane indywidualnie, co nastąpi wtedy, gdy każdej polisie będzie odpowiadała inna wartość składki (por. Bühl- 
mann i Gisler [2005]). Taki skrajnie zindywidualizowany system wyceny ryzyka jest obserwowany w przypadku polis w ubezpieczeniu komunikacyjnym OC/AC zawieranych na zasadzie Usage-Based (UBI). Oznacza to, iż ubezpieczony godzi się na instalację urządzenia elektronicznego w samochodzie pozwalającego na rzeczywisty pomiar różnego rodzaju czynników pomocnych dla wyceny spersonalizowanej ryzyka. Do zestawu takich czynników w systemie telemetrycznego kodowania można zaliczyć przykładowo faktyczną liczbę przejechanych kilometrów czy charakter obszaru, po którym porusza się w określonym momencie lub okresie pojazd samochodowy. Zakład ubezpieczeń wyznacza wtedy wartość tzw. składki PAYD (Pay-As-You-Drive) (zob. Desyllas i Sako [2013], Cieślik [2016]). Taki system zbierania danych jest nazywany telematyką (telematics). Na rynku polskim jednym z przykładów jest rozwiązanie Mobileye (zob. www1). Taki telemetryczny system kodowania historii przejazdu samochodu może być korzystny zarówno dla użytkownika samochodu tzn. ubezpieczanego jak i dla ubezpieczyciela. Powyższe rozwiązanie jest istotne dla firmy ubezpieczeniowe z uwagi na właściwości kryterium oceny tych firm. Istotne są tu dwie cechy charakteryzujące warunki polisy ubezpieczeniowej: wysokość składki ubezpieczeniowej oraz czas trwania likwidacji szkody. System telemetrycznego zapisu historii zdarzeń związanych z określoną polisą ubezpieczenia komunikacyjnego jest determinantą wpływająca bezpośrednio na $\mathrm{z}$ obniżeniem szkodowości a więc jednocześnie co się z tym łączy nierozłącznie wpływa na obniżenie składki ubezpieczeniowej. Jest truizmem stwierdzenie, że dla ubezpieczyciela oznacza to przyrost liczby klientów oraz pozyskanie dobrych kierowców, którzy nie generują szkód, gdyż tylko tacy kierowcy wyrażą zgodę na zapis telemetryczny ich historii przejazdów. Kolejną korzyścią jest zmniejszenie ryzyka tzw. fraudów ubezpieczeniowych, które wynikają z nieprecyzyjne umowy ubezpieczeniowej umożliwiającej popełnianie zwykłego przestępstwa na szkodę ZU. Z takimi przypadkami narażania ubezpieczyciela na nienależne koszty, często nie związanych z żadnym zaszłym zdarzeniem ubezpieczeniowym można się spotkać nie tylko w ubezpieczeniach komunikacyjnych. Wpływają one negatywnie nie tylko na finanse ubezpieczyciela (zwiększanie wypłat świadczeń), ale również w ubezpieczonych na ubezpieczanych ze względu na wzrost składek.

Dzięki telematyce ubezpieczyciel może znacznie łatwiej zrekonstruować przebieg wypadków. Mając takie dane jak prędkość, kierunek, siła uderzenia czy miejsce, ekspert od rekonstrukcji wypadków drogowych może znacznie łatwiej stwierdzić, czy w danym przypadku dochodzi do próby wyłudzenia (np. samochód został zniszczony nie w wypadku, ale celowo uszkodzony podczas postoju). 
Dążenie do coraz większej personalizacji składki ubezpieczeniowej powoduje, iż zakłady ubezpieczeń posiadają coraz więcej informacji, które mogą być brane pod uwagę w procesie wyceny ryzyka. Rodzi się zatem problem w jaki sposób wykorzystać zebrane dane. W obecnej praktyce, w masowych portfelach polis, wyznaczenie wartości składki dla polisy opiera się na modelu statystycznym, w którym estymuje się jego parametry czerpiąc informacje $\mathrm{z}$ danych zawartych $\mathrm{w}$ portfelu polis. Ujmując to językiem statystycznym, czerpie się informacje z próby. Modele te są modelami regresyjnymi klasy GLM, czyli uogólnionymi modelami liniowymi, por. Antonio i Valdez [2012], Wolny-Dominiak [2014]. Wraz z coraz bardziej szczegółowymi danymi, jak również rozwojem algorytmów numerycznych, uzasadnione jest modyfikowanie stosowanych obecnie modeli statystycznych, por. Muermann i Straka [2011], Weidner i in. [2016]. Właściwym kierunkiem może okazać się tu wspomniana na wstępie jakościowa forma wyceny ryzyka, która w ostatecznej procedurze wyznaczania składki z wyprzedzająca procedurą jej wyceny formalnej I tak ma zawsze charakter jakościowy wynikający z analizy rynku ubezpieczeniowego I obserwacji poziomu składek konkurencji w tej branży. .

\section{Określenie potencjalnego ryzyka na podstawie oszacowanych poziomów zagrożenia i podatności zasobu na zagrożenie oraz wartości tego zasobu}

Szacując ryzyko metodą jakościową korzysta się często z predefiniowanych zakresów wartości rożnych parametrów procesu szacowania ryzyka jak i z wszelkiego rodzaju miar opisowych (np. możliwość realizacji jakiegoś zagrożenia opisuje się, jako „niską”, „średnią” lub „wysoką”). Dla uzyskania konkretnych wartości stosuje się najczęściej metody ankietowe, w których wypełniana ankieta kierowana jest do właścicieli informacji i innych osób, których wiedza może być przydatna w procesie analizy ryzyka. W przykładzie potencjalne ryzyko narażenia obiektu - linii biznesowej na straty powiązane będzie, poprzez takie wartości, z poziomem zagrożenia, poziomem podatności zasobu odpowiadającego danej linii biznesowej - obiektowi wyeksponowaniu na ryzyko oraz wartością tego zasobu linii biznesowej, który w wyniku wyeksponowania na ryzyko może być całkowicie stracony lub tylko częściowo. 
Dla uproszczenia przyjmiemy, że:

a) wartość zasobu jest predefiniowana oceną z zakresu od 0 do 3,

b) zidentyfikowanym uprzednio zagrożeniom i grupom zasobów odpowiadających poszczególnym liniom biznesowym, które poddane są ekspozycji na ryzyko przypisuje się miarę poziomu zagrożenia w skali: niska, średnia, wysoka.

Wielkość poziomu zagrożenia może być określona różnorodnie i zależy np. od:

- atrakcyjności zasobu, łatwości zamiany zdobytego zasobu w dobro przynoszące określony zysk pieniężny lub inny, zdolności dokonywania działań wywołujących zagrożenie (w przypadku zamierzonego zagrożenia (np. terrorystycznego) spowodowanego przez czynnik ludzki);

- możliwości wystąpienia zagrożenia (w znaczeniu potocznie stosowanego określenia „prawdopodobieństwa”);

- stosowności podatności zasobu na wykorzystanie (technicznej zasobu lub innej);

c) przyjmuje się arbitralnie punktową skalę miary ryzyka w liczbach naturalnych z przedziału $[0,10]$.

\section{Przykład 1. Szacowania ryzyka wartości zasobu}

Dla zasobu z danej linii biznesowej wyznacza się podatność na zagrożenie w skali $N$ (niska), $S$ (średnia) i $W$ (wysoka) i odpowiadające jej zagrożenie. Podatności na zagrożenie może nie być przyporządkowane żadne zagrożenie i odwrotnie, zagrożeniu podatność, co oznacza, że nie występuje wtedy ryzyko naruszenia wartości zasobu. W sytuacji występowania takiego ryzyka, wartości zasobu równej np. 2 ze skali $(0,1,2,3)$ przyporządkowuje się poziom zagrożenia np. Ś i temu poziomowi w skali też $N, S, W$ odpowiada ryzyko według przyjętego schematu od 1 do 10.

Pokazane to jest $\mathrm{w}$ przykładzie $\mathrm{z}$ dwoma wartościami zasobu.

\begin{tabular}{|c|c|c|c|c|c|c|c|c|c|c|}
\hline \multirow{2}{*}{$\begin{array}{c}\text { Szacowane } \\
\text { ryzyko }\end{array}$} & Poziom zagrożenia & \multicolumn{3}{|c|}{ Niski } & \multicolumn{3}{|c|}{ Średni } & \multicolumn{3}{c|}{ Wysoki } \\
\cline { 2 - 13 } & Poziom podatności & $N$ & $S$ & $W$ & $N$ & $S$ & $W$ & $N$ & $S$ & $W$ \\
\hline $\begin{array}{c}\text { Wartość } \\
\text { zasobu }\end{array}$ & 2 & 5 & 6 & 7 & 6 & 7 & 8 & 7 & 8 & 9 \\
\cline { 2 - 13 } & 3 & 6 & 7 & 8 & 7 & 8 & 9 & 8 & 9 & 10 \\
\hline
\end{tabular}

Źródło: opracowanie własne.

$\mathrm{Z}$ tabeli wynika, że najbardziej wyeksponowany na ryzyko (ocenione na 10 w skali od 0 do 10) jest zasób o wartości ocenionej najwyżej na poziomie 3 , gdy poziom zagrożenia jest wysoki i w jego zakresie podatność na zagrożenie jest także wysokie. 
Natomiast przykładowo, gdy wartość zasobu (linia biznesowa) jest wyceniona na 2 , to przy średnim poziomie zagrożenia i niskiej podatności na zagrożenie, wyeksponowanie na ryzyko obiektu $z$ danej linii biznesowej wycenione jest na 6. Rozmiar tej tabeli - wyznaczony jest liczbą kategorii zagrożenia, podatności i wartości zasobów i zależy od wyeksponowania na ryzyko ubezpieczanego obiektu firmy.

\section{Ocena ryzyka względem poziomu zagrożenia i wagi (wartości zasobów) niekorzystnych dla firmy skutków zdarzenia}

Analiza ryzyka może też mieć na celu jego jakościową ocenę i powinna umożliwić decydentowi stwierdzenie w odpowiedniej hierarchii, jakie zagrożenie wpływające na stopień ekspozycji na ryzyko ma największą wagę mierzoną wartością poziomu zagrożenia oraz jaka jest waga skutków dla firmy (ZU), które wywołuje (zwykle mierzone są one wartością zasobów, które są w obszarze oddziaływania tego zagrożenia). Powstały w wyniku takiej oceny ranking zagrożeń jest podstawą optymalnego zestawienia zagrożeń, co ma wpływ na uproszczenie analizy).

Sposób oceny ryzyka jest $\mathrm{w}$ tym przypadku mniej arbitralnie ujęty niż w poprzednim przykładzie i zależy dla danego zagrożenia od wyceny skutków wystąpienia zagrożenia i poziomu zagrożenia, który jest szacowany.

Z zaprezentowanych w poniższej tabeli danych wynika sposób wyceny ryzyka poszczególnych zagrożeń. Dla uproszczenia przyjmiemy, że występują 4 zagrożenia $(A, B, C, D)$, dla których oszacowane są skutki wystąpienia zagrożenia $(s)$ mierzone wartością zasobów wyrażonych kilkoma kolejnymi liczbami naturalnymi, które mogą się powtarzać, np. dwa różne zagrożenia mogą wywołać te same skutki mierzące wartość zasobu. W taki sam sposób oceniany jest poziom zagrożenia.

Z tabeli wynika, że ekspozycję na ryzyka najbardziej dotyczy zagrożenia $A$. $Z$ ceny skutków $s$ wystąpienia zagrożeń $A$ i $C$ wynika, że są takie same, na poziomie 2 , ale inna jest ocena $p z$ dla obu zagrożeń. Zagrożenie $A$ ma najwyższą ocenę poziomu $p z$. Stąd w rankingu zagrożeń występuje, jako najbardziej wpływające na eksponowanie ryzyka zagrożeń.

$\mathrm{W}$ rozpatrywanym tu wariancie oceny jakościowej ryzyka pojawia się możliwość porównania i kolejnościowego ustawienia rożnych zagrożeń według wartości ekspozycji na ryzyko $r$. W tworzeniu tego rankingu nie 
jest to uzależnione od wartości zasobu czy skutków wystąpienia zagrożeń ani poziomu podatności na wystąpienia zagrożenia.

Miary zastosowane w tym przypadku wymagały połączenia punktowych miar skutków i możliwości wystąpienia zagrożeń. W praktyce może być konieczne odniesienie realnych kosztów do zastosowanych tu empirycznych miar punktowych.

\begin{tabular}{|c|c|c|c|c|}
\hline $\begin{array}{c}\text { Rodzaj }(z) \\
\text { zagrożenia }\end{array}$ & $\begin{array}{c}\text { Ocena }(s) \\
\text { skutków }\end{array}$ & $\begin{array}{c}\text { Ocena poziomu } \\
\text { zagrożenia }(p z)\end{array}$ & $\begin{array}{c}\text { Wartość miary } \\
\text { ryzyka } r=(s p z)\end{array}$ & $\begin{array}{c}\text { Ranking } \\
\text { zagrożeń }\end{array}$ \\
\hline$A$ & 2 & 4 & 8 & 1 \\
\hline$B$ & 4 & 1 & 4 & 3 \\
\hline$C$ & 2 & 1 & 2 & 4 \\
\hline$D$ & 3 & 2 & 6 & 2 \\
\hline
\end{tabular}

Źródło: opracowanie własne.

W analizie ryzyka można uwzględnić też parametr oceny częstotliwości realizacji zagrożenia, odnoszący się do realizacji zagrożeń na podstawie poziomu zagrożenia i poziomu podatności (tak jak w przykładzie 1). Tak samo się go ocenia dla poziomów zagrożenia $N, S$, i $W$ względem tak samo klasyfikowanych poziomów podatności na zagrożenie (niski, średni, i wysoki). W szacowaniu tego parametru nie jest brana pod uwage wartość zasobu ani tym bardziej nie jest oceniana atrakcyjność zasobu w przypadku wywołania zdarzenia przez jego potencjalnego inicjatora z pewnych indywidualnych motywów. W tym przypadku mogą to być np. zwierzęta niszczące płody rolne.

\section{Podsumowanie}

Podjęty w artykule temat dotyka problematyki analizowanej z różnych punktów widzenia, a dotyczy szacowania zagrożeń wywołujących niekiedy ogromne straty, subiektywnie dobranych miar i ocen ryzyka niemających skwantyfikowanych podstaw $\mathrm{w}$ aspekcie formalizmu teorii ryzyka, by uznać je za oceny mogące być podstawą do ich ubezpieczenia zgodnie $\mathrm{z}$ ogólnie stosowaną $\mathrm{w}$ takich przypadkach formułą przyjmowaną $\mathrm{w} \mathrm{ZU}$. Zarys zaprezentowanej tu tematyki łączy się z wieloma podejmowanymi w literaturze próbami opisu sytuacji, gdy ewidentnie występują szkody wywołane rożnymi obserwowanymi w praktyce zagrożeniami. Przykła- 
dy subiektywnie wyrażanych ocen ilościowych omówione w rozdziale 5 artykułu wskazują na możliwości ujęcia ryzyka metodami jakościowymi. Badania nad takim ujęciem ryzyka niesformalizowanego, a więc $\mathrm{w}$ istocie niepewności, są dla praktyki szacowania strat wywołanych przez trudno wyceniane zagrożenia bardzo ważne ale wielu autorów wskazując na takie zagrożenia nie podaje reguł mogących być podstawą do wyceny składki w ZU dla takich ryzyk. Stąd najczęściej takie ryzyka są ubezpieczane w grupie ubezpieczeń od następstw nieszczęśliwych wypadków, a wypłacane odszkodowania są wtedy $\mathrm{z}$ reguły silnie zaniżone lub dochodzenie roszczeń rozciąga się niekiedy na długi okres.

Tematyka omówiona w artykule ujęta została teoretycznie, ale ma ona silne odniesienie praktyczne, chociaż w samej pracy nie zostało to szerzej uwidocznione. Dla dalszych badań ten aspekt wymaga właśnie bardziej pogłębionych studiów.

\section{Bibliografia}

Jędrzychowska A., Poprawska E., Ronka-Chmielowiec W. (2015), Problem ryzyka zakładu ubezpieczeń pochodzących z ubezpieczeń komunikacyjnych, „Studia Ekonomiczne ZN UE w Katowicach. Ekonomia" (3), nr 242.

Liderman K. (2003), Oszacowanie jakościowe ryzyka dla potrzeb bezpieczeństwa teleinformatycznego, ,Biuletyn Instytutu Automatyki i Robotyki”, nr 19, Warszawa.

Muślewski Ł. (2009), Evaluation Method of Transport Systems Operation Quality, „Polish Journal of Environmental Studies", vol. 18, no. 2A, Olsztyn.

Muślewski Ł., Woropay M. (2005), Theoretical grounds to evaluate of the transport system operation, Proceedings of the 12th International Congress of the International Maritime Association of Mediterranean - IMAM 2005, Maritime Transportation and Exploitation of Ocean and Costal Recources - Guedes Soares, Garbatov \& Fonseca, Taylor \& Francis Group, London.

Romanowska-Słomka I., Słomka A. (2008), Karty oceny ryzyka zawodowego dla 100 stanowisk pracy, SIGMA-NOT, ATEST, Kraków.

Szopa T. (2002), Podstawy analizy ryzyka zawodowego, Politechnika Warszawska.

Suh N.P. (1995), Designing-in of Quality Through Axiomatic Design, „IEEE: Transactions on Reliability", vol. 44, no. 2.

Wieteska S. (2016), Tendencja kształtowania się ryzyka porażenia prądem ludności w Polsce w latach 2005-2012, „Acta Universitatis Lodziensis. Folia Oeconomica”, no. 1(318), Wydawnictwo Uniwersytetu Łódzkiego.

[www1] http://www.mobileye.com/pl-pl/rynki/firmy-ubezpieczeniowe. 


\section{JAKOŚCIOWE SZACOWANIE PEWNYCH ZAGROŻEŃ GENERUJĄCYCH RYZYKO UBEZPIECZENIOWE}

W artykule podejmowany jest temat ujęcia zagrożeń w ubezpieczeniach w aspekcie systemowego zarządzania bezpieczeństwem ubezpieczanych obiektów (SZBUO). Główna uwaga skupiona zostanie na jakościowym szacowaniu ryzyka z reguły wywołanego zagrożeniami wywołującymi to ryzyko. Istotne przy takim podejściu do problematyki szacowania ryzyka jest dokonanie przeglądu metod szacowania ryzyka, co w praktyce przekłada się na problem projektowania i implementacji realizowany w systemie zarządzania bezpieczeństwem ubezpieczonych obiektów (SZBUO). Najczęściej w takim przypadku ryzyka są ubezpieczane w grupie ubezpieczeń od następstw nieszczęśliwych wypadków, a wypłacane odszkodowania są wtedy z reguły silnie zaniżone lub dochodzenie roszczeń rozciąga się niekiedy na długi okres.

Zarządzanie bezpieczeństwem ubezpieczanych obiektów leży, jeśli jest to możliwe w praktycznym interesie Zakładu Ubezpieczeń (ZU) i sprowadza się do doboru adekwatnej metody względem ubezpieczanego ryzyka indywidualnego lub grupy ryzyk (obiektu) w instytucji lub firmie. $Z$ reguły uzasadnione to jest potrzebą stworzenia podstaw dla uzyskania rozwiązań systemowych skierowanych ku doborowi najbardziej odpowiednich zabezpieczeń przed zagrożeniami niemającymi ważnych dla ZU podstaw do ich ubezpieczania.

Słowa kluczowe: system zabezpieczeń, zarządzanie ryzykiem, szacowanie ryzyka.

\section{QUALITY EVALUATION OF CERTAIN OF HAZARDS GENERATING RISK INSURANCE}

An article's subject is threats in insurance in systemic risk management aspect of security management of insuranced objects. Main focus in this article is put on quality risk assessment which is usually caused by threats that are causing that risk what is important in such an approach is to verify risk assesment methods which can be problematic in pracice in terms of projecting and implementation in systemic risk management aspectof security mamagement of insuranced objects. The most common in such group are objects insuranced in group of accident and casualty insurances and compensation that is paid is usually significantly low. Managing of security of insuranced objects is in the interest of Social Insurance Institution and lies in choosing an adequate method in regard to insuranced good. Keywords: security system, risk management, risk assessment. 